\title{
Effect of 12-week elastic-band resistance training on muscle quality and serum CAF in elderly women with osteocsarcopenic obesity: a randomized clinical trial
}

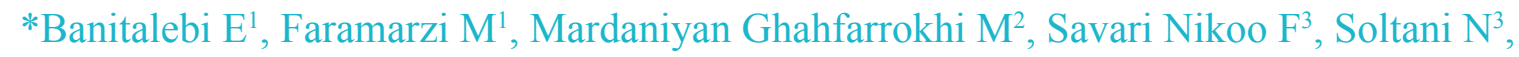

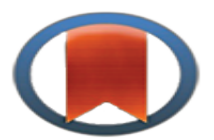

Bahram Zadeh $\mathrm{A}^{3}$

CrossMark

click for updates

1- Associate Professor in Exercise Physiology, Department of Sport Sciences, Shahrekord University, Shahrekord, Iran (Corresponding Author)

Email: banitalebi.e@gmail.com

2- PhD Student in Exercise Physiology, Department of Sport Sciences, Shahrekord University, Shahrekord, Iran. 3- Msc in Exercise Physiology, Department of Sport Sciences, Shahrekord University, Shahrekord, Iran.

\section{Abstract}

Introduction: Osteosarcopenic obesity results from musculoskeletal degradation and increase in fat tissue. The purpose of this study was to investigate the effect of 12 weeks elastic-band resistance training on muscle quality and serum CAF in elderly women with osteosarcopenic obesity.

Method: In this single blind randomized clinical trial, 48 elderly women with osteosarcopenic obesity (based on the results of the DEXA test, age $64.63 \pm 3.68$, fat percentage $45.4 \pm 6.6$, BMI $3.71 \pm 1 / 33$, T score of bone minerals density of femur and 1-4 lumbar spine $-1.86 \pm 1.42)$ were randomly divided to control $(\mathrm{n}=$ $22)$ and exercise $(n=26)$ groups. The training group performed 12 weeks and three sessions at week elasticband resistance training for all major muscle groups. 48 hours before and after 12 weeks of intervention, a DEXA-test was performed and blood samples were taken. Independent sample t-test was used for withingroup comparisons and two-way ANOVA (group* time) was used for comparison between groups.

Results: The results of statistical analysis showed that after 12 weeks of elastic-band resistance training as a result of between-group comparisons, there was a significant difference in muscle quality $(\mathrm{P}=0.043)$, osteosarcopenic obesity $\mathrm{Z}$ score $(\mathrm{P}=0.303)$, and hand grip $(\mathrm{P}=0.013)$ was observed between the training and control groups. However, there were not observed significant difference in weight $(\mathrm{P}=0.440)$, body mass index $(\mathrm{P}=0.354)$, fat percentage $(\mathrm{P}=0.093)$, $\mathrm{BMC}(\mathrm{P}=0.001), \mathrm{BMD}(\mathrm{P}=0.564)$ gait speed $(\mathrm{P}=0.22)$ and CAF $(\mathrm{P}=0.501)$.

Conclusion: According to the results of this study, it seems that elastic-band resistance training improves muscle strength, muscule quality and the status of osteosarcopenic obesity ( $\mathrm{Z}$ score) in elderly women with osteosarcopenic obesity. Also, due to the lack of significant changes in CAF, at least in this study, CAF is not confirmed as a powerful indicator of muscle quality and physical function.

Keywords: Osteosarcopenic obesity, Resistance training, Elderly, muscle quality, C-Terminal Agrin Fragment (CAF).

Received: 25 May 2019

Accepted: 15 July 2019

\begin{tabular}{|l|l|}
\hline \multicolumn{3}{|c|}{ Access this article online } \\
\hline
\end{tabular}




\section{تأثبر Yl هفته تمرين مقاومتى با باند كشى بر كيفيت عضلانى و غلظت سر مى CAF در زنان سالمند

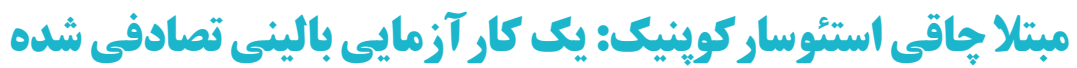

"قابراهيه بنى طالبى'، محمد فرامرزى'، مجيد مردانيان قهفرخىّ، فريده سوارى نيكوّ، ندا سلطانىّ، آزيتا بهرام زادهّ

ا-دانشيار فيزيولوزى ورزشى، گروه علوم ورزشى، دانشكده ادبيات و علوم انسانى، دانشكاه شهركرد، شهركرد، ايران (نويسنده مسئول) يست الكترونيكى:

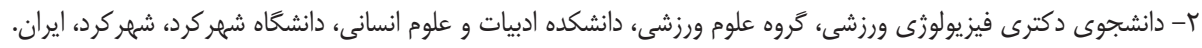

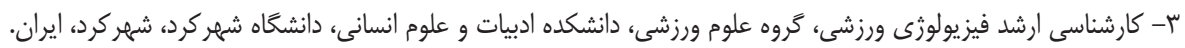

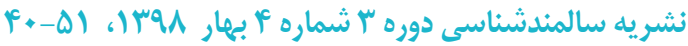

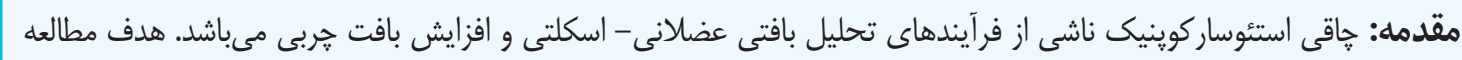

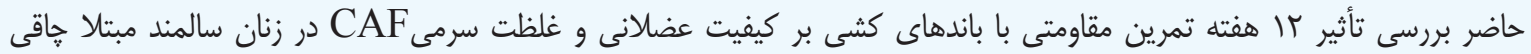
استئوسار كوينيك است.

روش: در اين كارآزمايى بالينى تصادفى شده يك سو كور، ب^ زن سالمند داراى خاقى استئوساركوينيك (بر اساس نتايج آزمايش

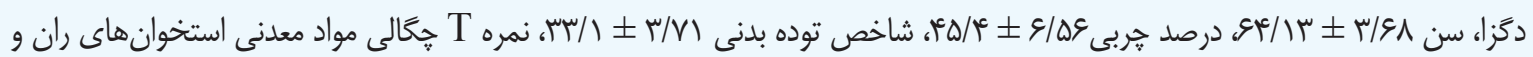

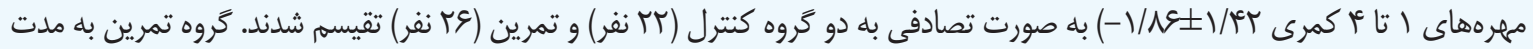

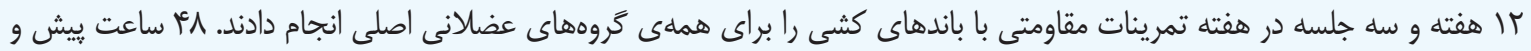

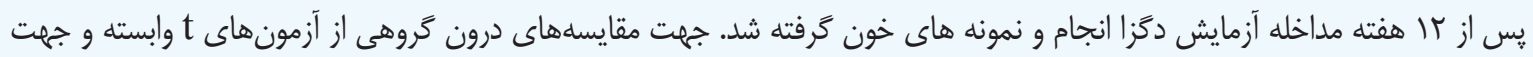

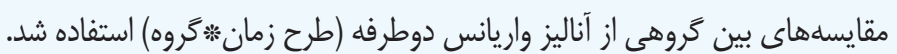

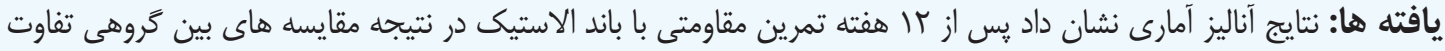

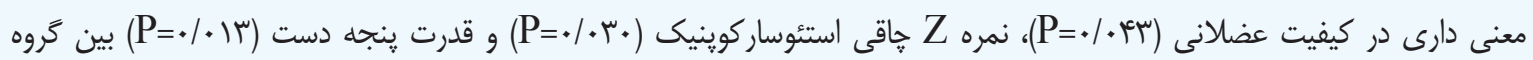

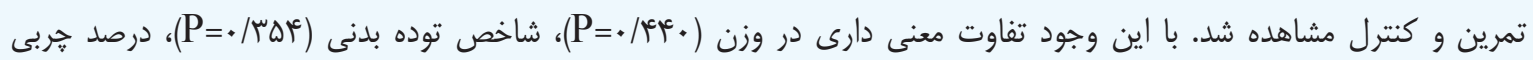

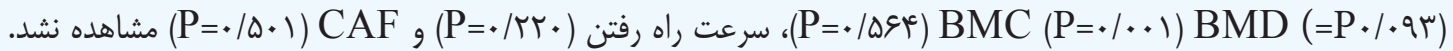
نتيجه كَيرى: با توجه به نتايج يزوهش به نظر مى رسد تمرين مقاومتى با باند الاستيك موجب بهبود قدرت عضلانى، كيفيت

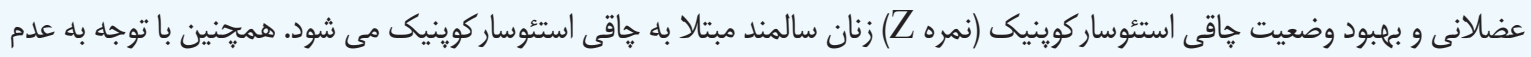

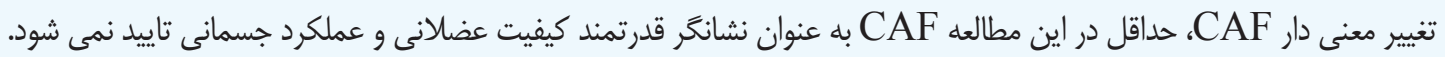
كليدوازه ها: جاقى استئوسار كوينيك، تمرين مقاومتى، سالمند، كيفيت عضلانى، قطعه بايانه C آكَرين.

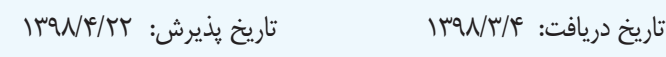

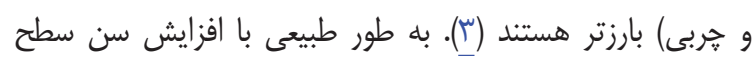
مقلdمه

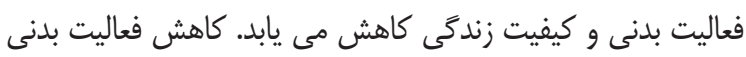
موجب كاهش توده عضلانى و استخوانى و به طبع آن كاهش عملكرد عضلانى - اسكلتى مى شود (أ). بر خلاف بافت عضلانى

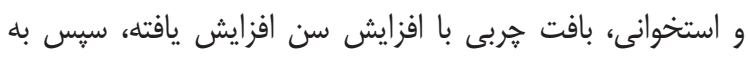

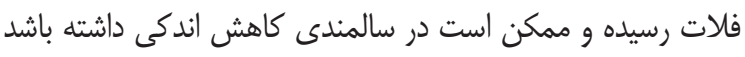

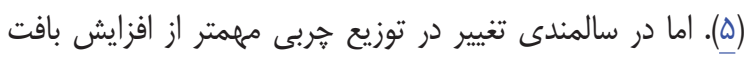
קربى است. با افزايش سن جربى احشايى و نفوذ هربى در داخل جمعيت سالمند در سراسر جهان به شدت در حال افزايش است. با توجه به يِي بينى هاى انجام شده جمعيت سالمند جهان تا سال •م.r حدود r ميليارد نفر خواهد بود ((). سالمندى بي بيامد هاى ناكوار متعددى از جمله افزايش خطر بيماريهاى متابوليك و به دنبال آن هزينه هاى ززاف مراقبت هاى سلامتى را به همراه دارد (Iآ). سالمندى همجنين موجب تغييرات فيزيولوزيكى متعددى مى شود كه تغييرات تركيب بدنى (بافت هاى عضلانى، استخوانى 
عنوان بازسازهاى واقعى بافت معرفى شده اند. يكى از اين نشانكر

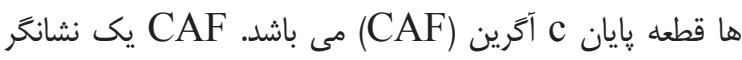

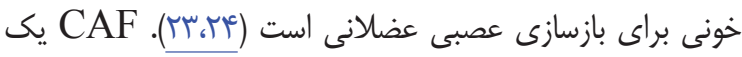

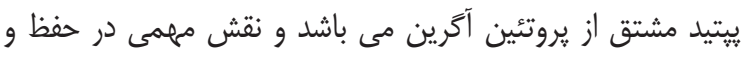

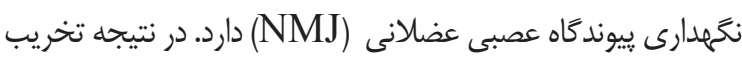
اتصال عصبى عضلانى و عصب زدايى تار عضله اسكلتى، آَكرين تحت فعاليت آنزيم نروترويسين سينايسى شكسته شده و و

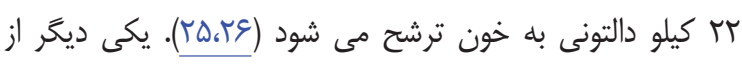
تغييرات فيزيولوزيك ناشى از سالمندى كاهش عملكرد عصبى است

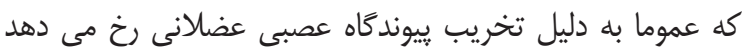
(TV)

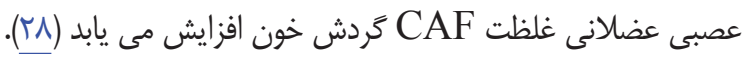

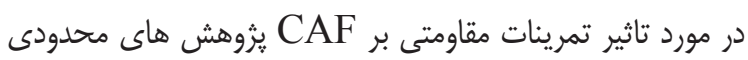
صورت كرفته و نتايج متناقضى در دسترس است. فراكالا و همكاران

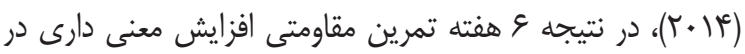
سطوح CAF خون افراد سالمند مشاهده كردند (وَ). نشان داده

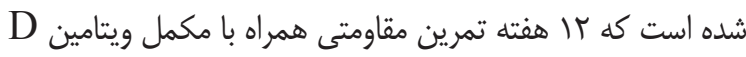
موجب كاهش معنى دار سطوح CAF سالمندان مى شود (• مَّ).

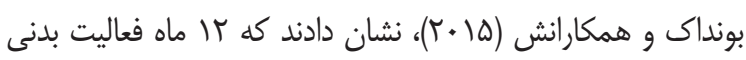
سازمان يافته (شامل تركيبى از انواع تمرينات ورزشى) تاثير معنى نانى

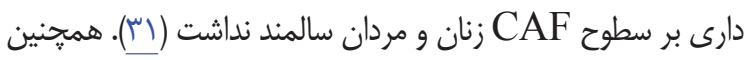

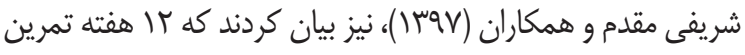

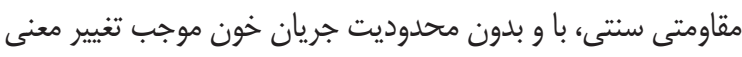
دارى در سطوح CAF زنان سالمند نمى شود (YI). بر اساس ادبيات موجود مطالعات اندكى و متناقضى در مورد تاثير تمرين مقاومتى بر كيفيت عضلانى و CAF در زنان سالمند

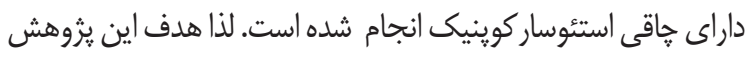
بررسى تاثيرات II هفته تمرين مقاومتى با باندكشى بر كيفيت

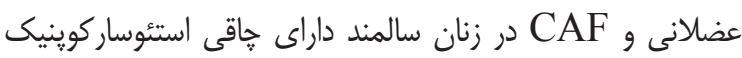
مى باشد.

\section{ورش مطالعه}

اين يزوهش يك كارآزمايى بالينى تصادفى (RCT) يك سو كور مى باشد كه بر اساس بيانيه كانسورت (CONSORT) براى آزمايشهاى تصادفى درمان غيرداروئى انجام شد (بسّبسا).

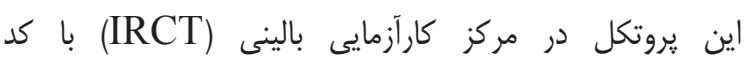

بافت عضله اسكلتى افزايش مى يابد كه ييامد آن كاهش قدرت،

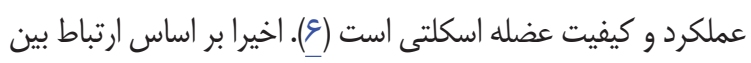
كاهش توده عضلانى و اسكلتى و افزايش توده هربى در سالمندان

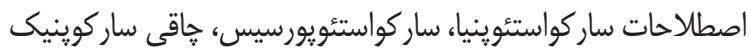
و واقى استئوسار كوينيك (SO)

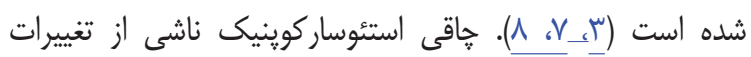

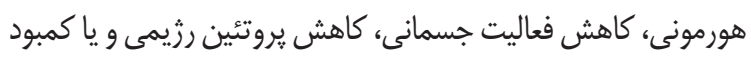
ويتامين D و همجنين افزايش سطوح جربى است و با برخى شرايط كاتابوليسمى ناشى از التهاب مزمن، و يوكى استخوان همراه است

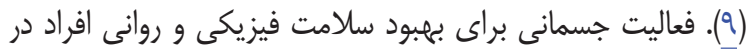

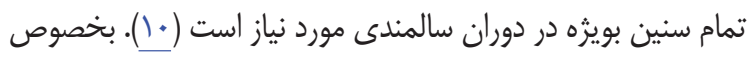
در مورد سندرم OSO، فعاليت جسمانى حتى در شدتهاى كم و متوسط، براى حفظ و بهبود قدرت و كيفيت عضلانى، بهبود تعادل و دامنه ى حركتى در سالمندان ضرورى است (1)). از اين رو تمرينات مقاومتى سبب افزايش قدرت عضلانى و هييرتروفى مى شوند (IT) (IT). تمرين مقاومتى مى تواند جهت كاهش اثرات مرتبط با هاقى

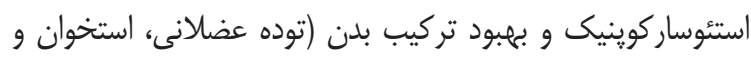

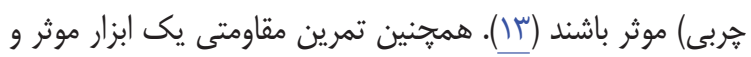
مناسب جهت مقابله با ضعف عضلانى و ناتوانى، بهبود قدرت، اندازه، عملكرد و كيفيت عضلانى (أ|-18) حتى براى افراد سالمند بيشتر از •م سال است (V)). روشهاى تمرين مقاومتى سنتى يا وزنه هاى آزاد، استرس شديدى بر سيستم عضلانى - اسكلتى و مفاصل وارد

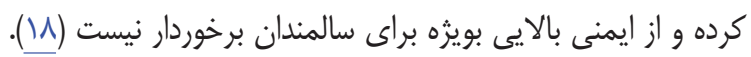

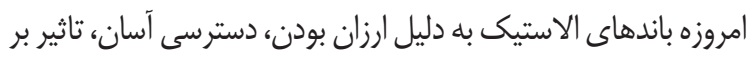

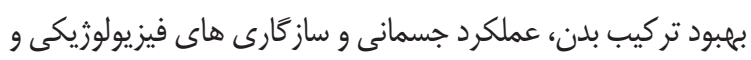

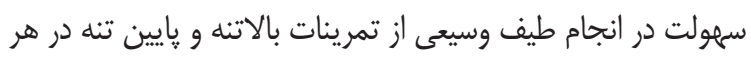

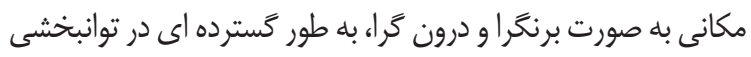

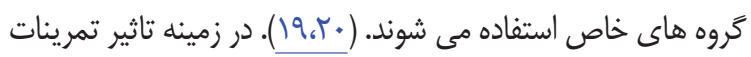
مقاومتى بر كيفيت عضلانى هافمن و همكاران نشان دادند كه

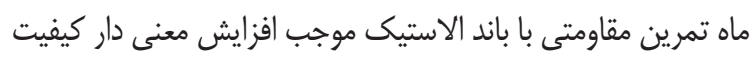

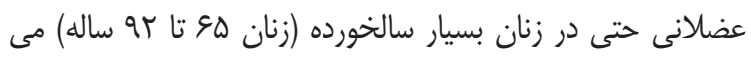

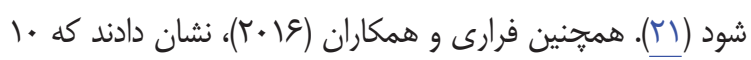

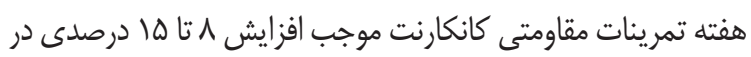
كيفيت عضلانى مردان سالمند مى شود (بآ).

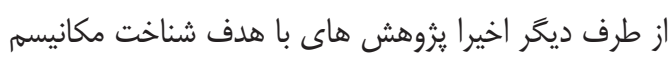

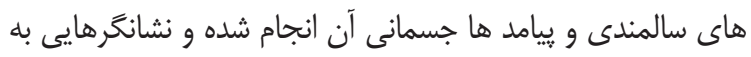


به صورت بلوكهاى دوتايى انجام شد. مربيانى كه در جمع آورى داده

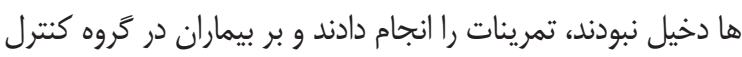

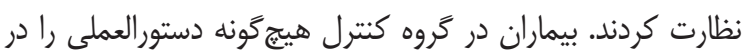
مورد تغيير رزيم غذايى معمول و فعاليتهاى بدنى خود، در طول دوره مطالعه دريافت نكردند و در هيج برنامهاى براى تغذيه يا تمرين شركت نكردند. بيماران در گروه كنترل به صورت تماس تلفنى و يا مصاحبه حضورى، يك بار در هفته مورد كنترل قرار مى گرفتند. در طول اين بازديدهاى هفتكى، مشكلات بهداشتى، مشكلات

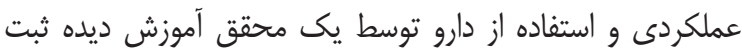

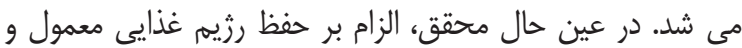

$$
\text { رويههاى فعاليت روزانه را تاكيد مى كرد. }
$$

جس از اندازهگيرىهاى آزمون هاى عملكردى اوليه، از از

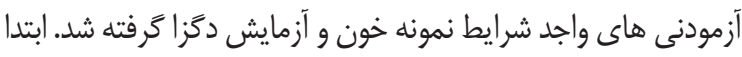
و به مدت r هفته و سه جلسهى يك تا يك و نيهم ساعته در هر هفته نمانه تمرينات مقاومتى با باند كشى با استفاده از باند زرد رنح جهت آشنا

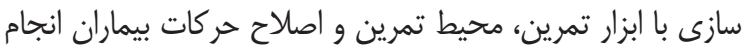
شد. سبس، برنامه تمرين به مدت كا هفته آغاز شد. بعد از اتمام

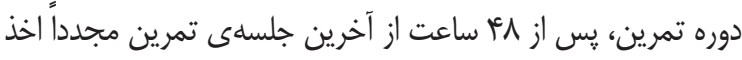

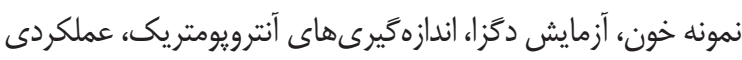

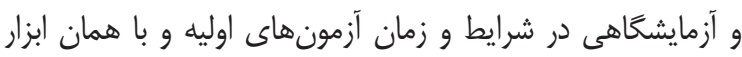
توسط محقق و متخصص آزمايشخاه انجام يذيرفت. همجنين شرايط OSO بيماران با استفاده از فرمول زير بررسى شد.

\section{فرمول شاخص OSO}

(Muscular strength Z-core) + (SMM Z-score) + $(1-\times$ body fat $\mathrm{Z}-$ score $)+($ BMD Z-score $) / \%$

روش تمرينى در طول r جلسه قبل از شروع يروتكلهاى

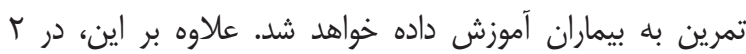
جلسه اول، بيماران جهت كنترل شدت ورزش با استفاده از تعداد

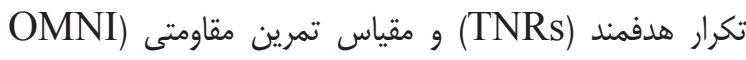

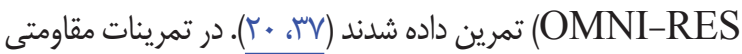
با كش الاستيك بيماران با افزايش يا كاهش فاصله دست ها به

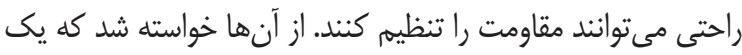

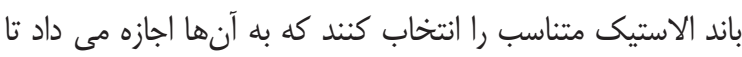
را انجام دهند (r. RM- r.

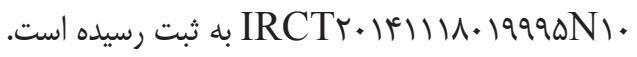

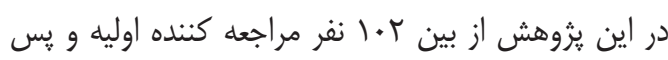
از بررسى شرايط ورود و خروج از مطالعه كس نفر به دليل نداشتن شرايط ورود به مطالعه و \نفر به دليل انصراف از شركت در

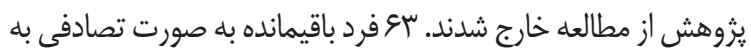

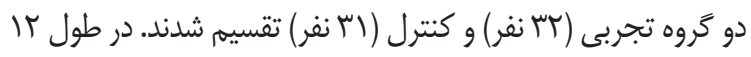

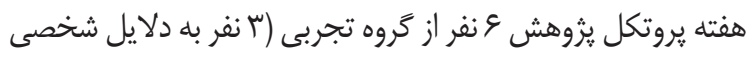

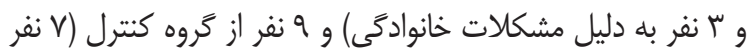
به دلايل شخصى، ا نفر به دليل مشكلات خانوادگى و ا نفر به دليل تغيير مكان زندگى) از ادامه يزوهش حذف شدند. نهايتا وب نفر در گروه تجربى و זr نفر در گروه كنترل مطالعه را به קيايان رساندند

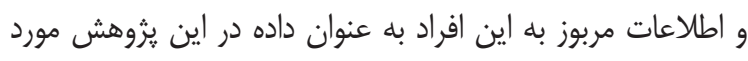

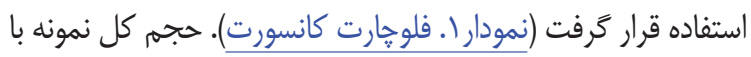

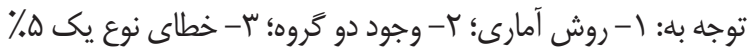

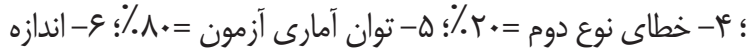
اثر = • r/ • با استفاده و نرم افزار 1ץ نفر محاسبه شد. حجم نمونه نهايى سه نفر يس از يِيش بينى

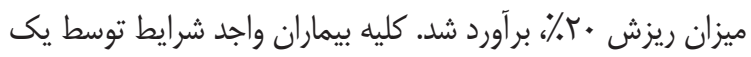
يزشك انتخاب شدند. در اين مطالعه بيماران واجد شرايط با استفاده

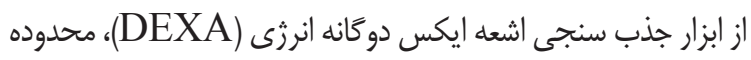

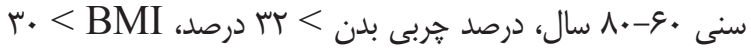

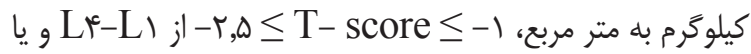

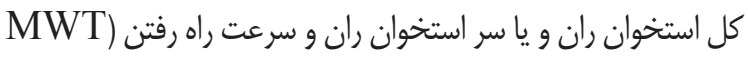

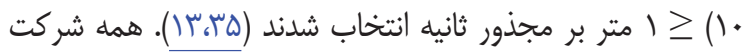

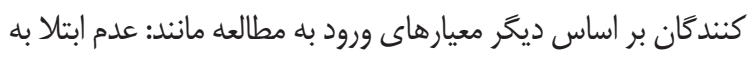

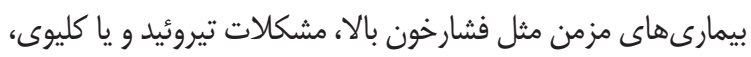
سرطان، ديابت يا يوكى استخوان خيلى شديد (ه/T-score > نيز مورد بررسى قرار كرفتند. همجنين عدم استفاده از هورمون درمانى، عدم داشتن تمرين منظهم بيشتر از •ب دقيقه در طول هفته طى شش ماه كَنشته، عدم مصرف مكمل هاى غذايى در طى بـ ماه

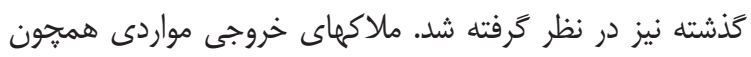
تمرينات جسمانى موازى، ييروى از رزيم كاهش دهنده وزن بيشتر از ه كيلو گرم در سه ماه كذشتها، هورمون درمانى و يا مصرف هر دارويى كه روى تراكم استخوان، بافت هربى و يا سيستم هورمونى تاثير گذار

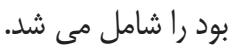
رضايت آكاهانه از تمام بيماران بعد از ارزيابى اوليه و

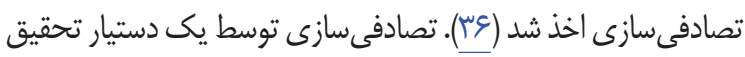



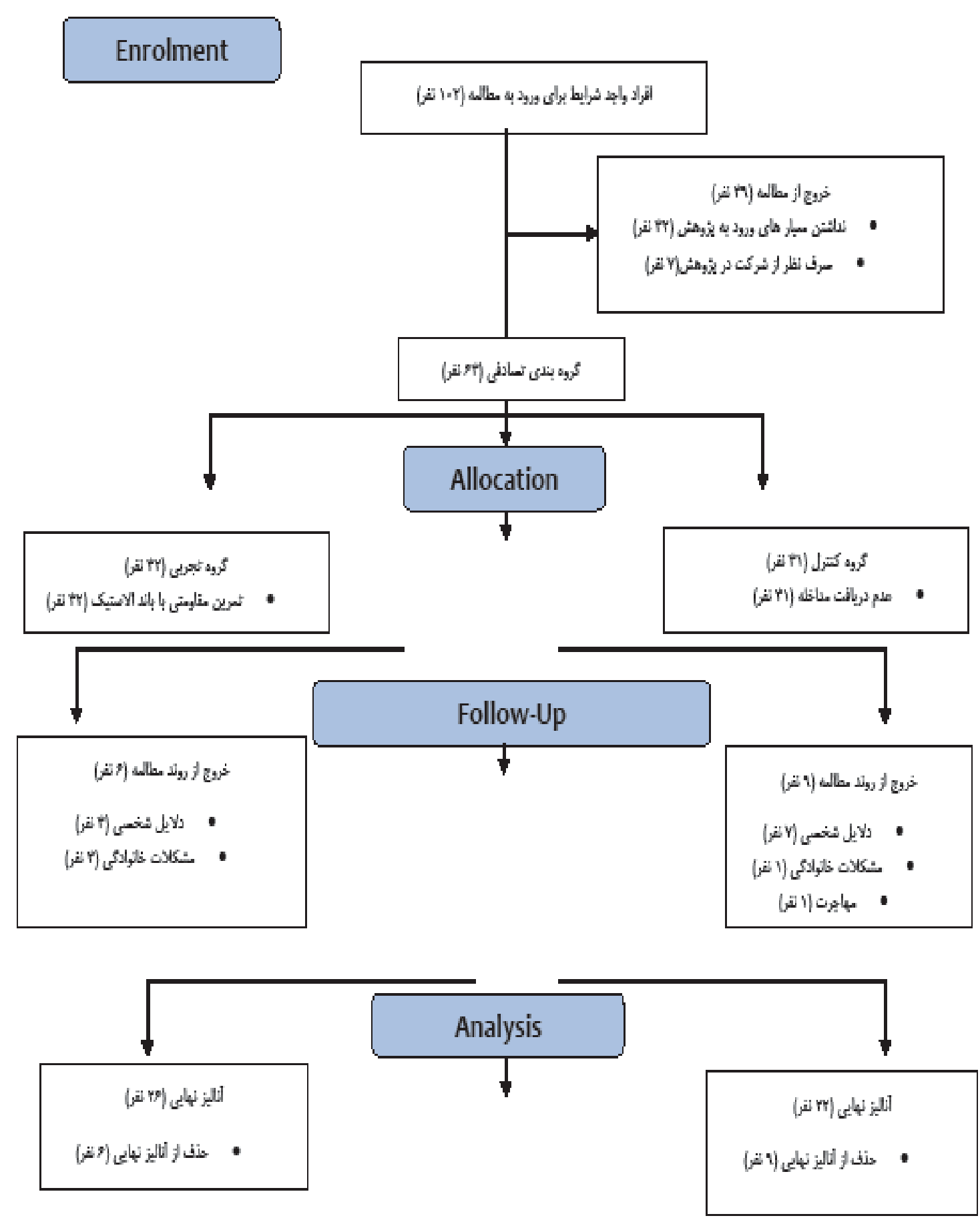

نمودار (: فلوجارت كانسورت

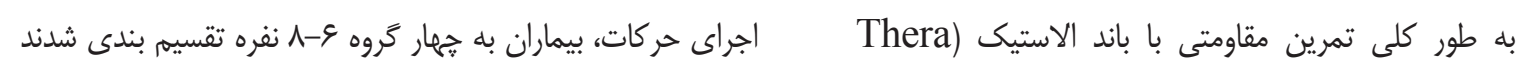

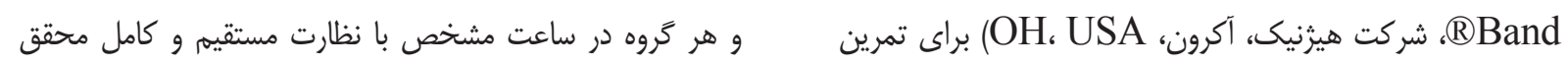

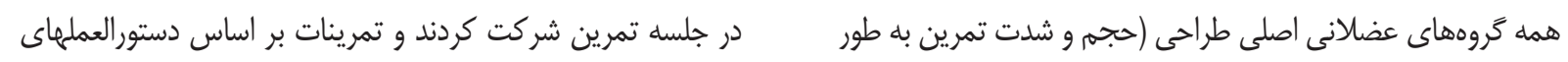

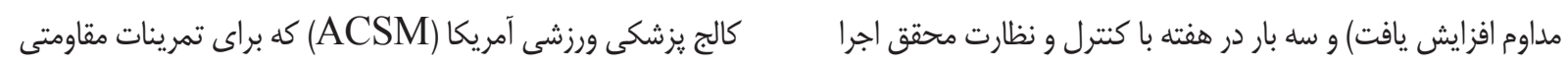

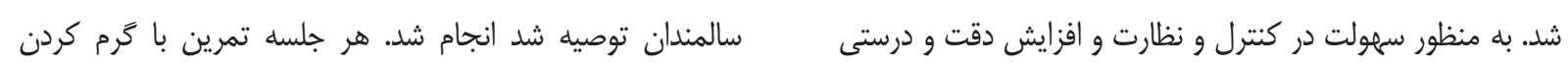




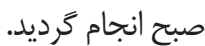

سطوح CAF در سطح سرم، به روش الايزا و با كيت

NTCAF ELISA, Neurotune AG, Schlieren-) (Zurich, Switzerland BMD، BMC

$$
\text { يخوهش توسط آزمايش دَزا اندازه خيرى شد. }
$$

جهت تجزيه و تحليل آمارى در اين يُوهش از ميانكَين

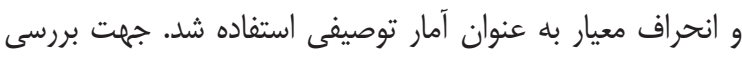
نرمال بودن دادها از آزمون كولموكروف-اسميرنوف استفاده شد. جهت مقايسه كَروه ها در ييش آزمون از آزمون t مستقل استفاده

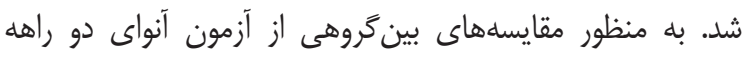

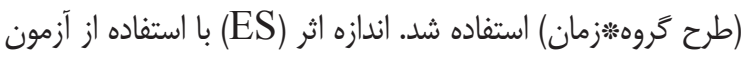
Partial Eta squared

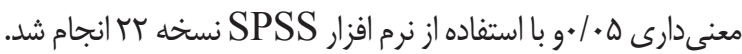

عمومى •ا دقيقهاى شروع مى شد، سِّ تمرينات مقاومتى با

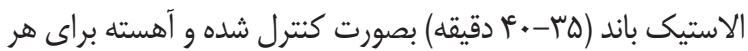
يك از شش گروه عضلانى (ياها، يشت، شكم، قفسه سينه، شانه و بازو) انجام شد و با ه دقيقه زمان براى سرد كردن جلسه تمرين به

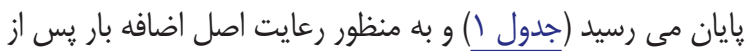

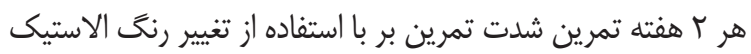
باند افزايش يافت كه بر همين اساس آنها به ترتيب از زرد به قرمز،

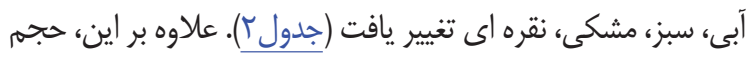
تمرين با افزايش تعداد ستها از يك به دو ست و ميزان ييشرفت بر اساس بهبود فردى (اكر بيمار قادر به انجام دو تكرار بيشتر در ست

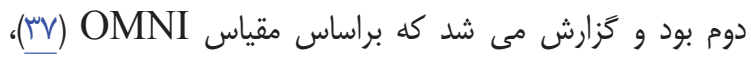

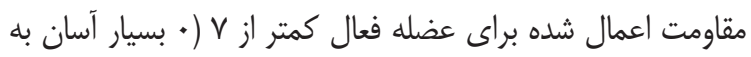
• ( بسيار سخت) است و رنخ كش تغيير مى يافت) افزايش يافت.

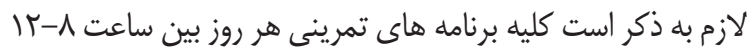

\begin{tabular}{|c|c|c|c|}
\hline (دقيقه) & كروه عضلانى درَير & شدت (ست/ تكرار) & نوع حركت \\
\hline \multicolumn{4}{|r|}{ كرم كردن } \\
\hline $\begin{array}{l}\Delta \\
\Delta\end{array}$ & 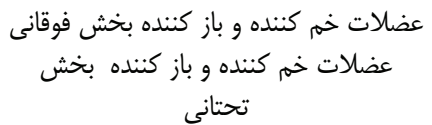 & - & 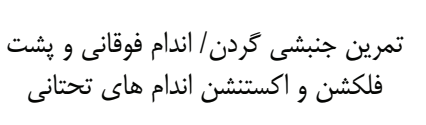 \\
\hline \multicolumn{4}{|r|}{ بخش فوقانى } \\
\hline 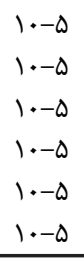 & 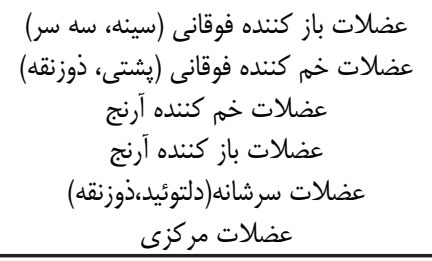 & 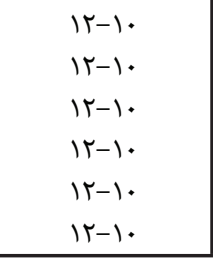 & 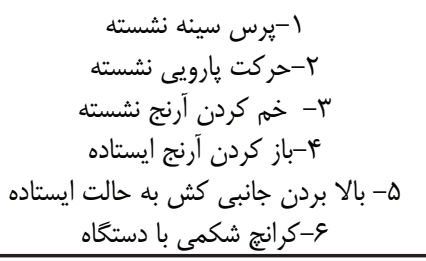 \\
\hline \multicolumn{4}{|r|}{ بخش تحتانى } \\
\hline $\begin{array}{l}1 \cdot-a \\
1 \cdot--\infty \\
1 \cdot--\infty \\
1 \cdot--\infty \\
1 \cdot--\infty \\
1 \cdot-\infty \\
1 \cdot-\infty \\
1 \cdot-\infty\end{array}$ & 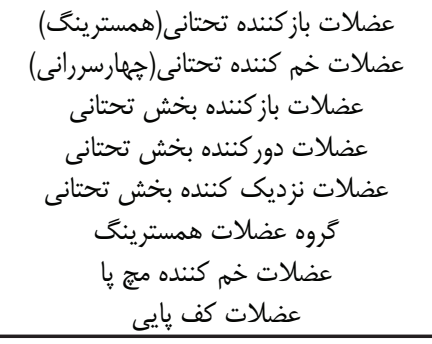 & 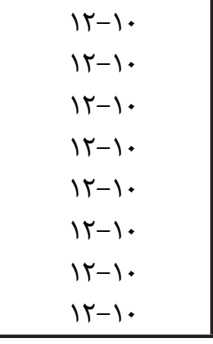 & 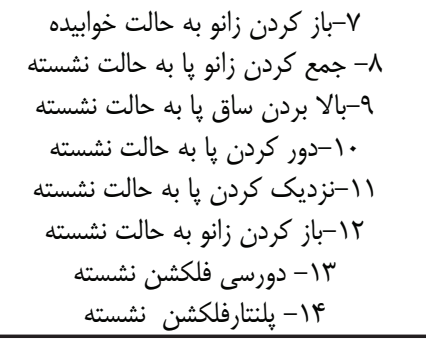 \\
\hline$\Delta$ & & & سرد كردن \\
\hline شد. & 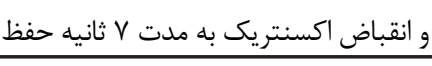 & نتريك براى ץ ثاني & "***نكته: در هر حركت مدت انقباض \\
\hline
\end{tabular}




\begin{tabular}{|c|c|c|c|c|c|c|c|}
\hline$|r-1|$ & & & & & 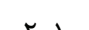 & & \\
\hline$*$ & $*$ & * & * & * & $*$ & سبر سبى سرز & رنح باند كشى \\
\hline $\begin{array}{c}1,-1 . \\
r-1 . \\
r-1 .\end{array}$ & 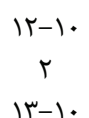 & $\begin{array}{c}1,-1 . \\
t \\
1 \\
t-1 .\end{array}$ & $\begin{array}{c}t r-1 . \\
t \\
1 k-1 .\end{array}$ & $\begin{array}{c}1 r-1 . \\
r-1 . \\
r-1 .\end{array}$ & $\begin{array}{c}\mid r-1 . \\
1 \\
1\end{array}$ & تكرار & بار تمرين \\
\hline
\end{tabular}

تمرين و كنترل مشاهده شد. با اين وجود تفاوت معنى دارى در وزن

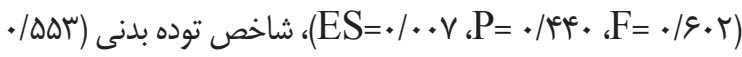
• F نتايج آناليز آمارى نشان داد تفاوت معنى دارى در ييش آزمون در $\mathrm{ES})=\cdot /$ Nعr، $\mathrm{P}=\cdot / \cdot+1, \mathrm{~F}=\cdot / \cdot r \cdot) \mathrm{ES} \mathrm{BMC}=\cdot / \cdot r \cdot \mathrm{P}=$ (هس BMD

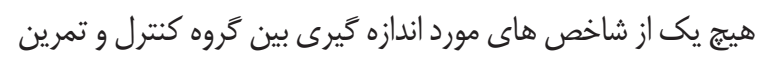

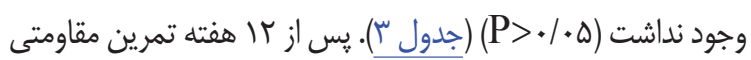

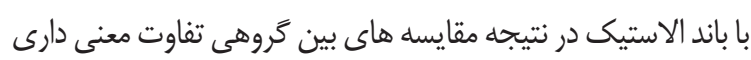

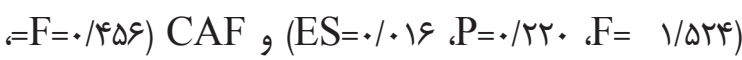

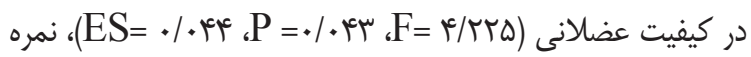

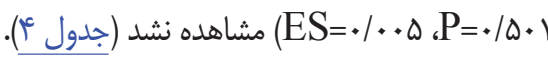

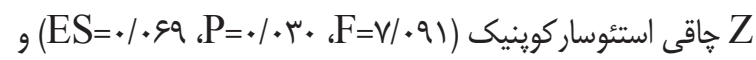

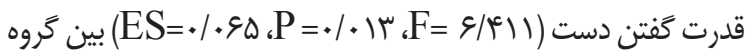
جدول ب: مقايسه سطوح يايه شاخص ها كَروه كتترل و تجربى

\begin{tabular}{|c|c|c|c|c|}
\hline P-value & $\mathrm{T}$ & بيش آزمون & كور & 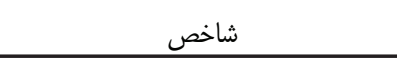 \\
\hline.$/ 918$ & $-.1 .9 \mathrm{~V}$ & $\begin{array}{l}s \psi / \cdot \Delta \pm r / r \Delta \\
s \psi / 11 \pm r / \Lambda 1\end{array}$ & كتنترل & سن (سال) \\
\hline . &.$- / 4 r q$ & $\begin{array}{l}1 \Delta \Delta / V \gamma \pm \kappa / l \digamma \\
\mid Q \Delta / \Delta q \pm \kappa / \mu \Lambda\end{array}$ & كتربي & قد (سانتى متر) \\
\hline 促. & $-1 / / r \mid$ & $\begin{array}{l}V N / N r \pm V / \Delta T \\
\Lambda N / \Lambda) \pm N \cdot r\end{array}$ & تجنترل & وزن (كيلوكَم) \\
\hline $.1 .9 \mathrm{~V}$ & $-I / M A V$ & $\begin{array}{l}r \psi / q . \pm r / q q \\
\kappa \varepsilon / r q \pm r / q r\end{array}$ & 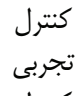 & درصد جربى (\%) \\
\hline.$/ 401$ & $-\cdot /$ VY) & $\begin{array}{l}r r / Q T \pm r / \cdot 1 \\
r / V T \pm r / / Q\end{array}$ & 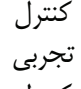 & شاخص توده بدنى (كيلوكرم بر متر مربح) \\
\hline •/ $/ 41 \mid$ & $-\cdot / \Lambda \Delta$ & 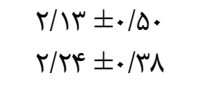 & كتربى & (كر) BMC \\
\hline$\cdot / V^{c}$ & ./19४ & $\begin{array}{l}1 / * \Delta \pm \cdot / F \Delta \cdot \\
\cdot / q T q \pm \cdot / \Gamma F \Delta\end{array}$ & تجربى كنت & BMD (كرم بر سانتى متر مربع) \\
\hline$\cdot /$ r & •/NVQ & 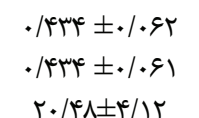 & كتربتى كنت & سرعت راه رفتن (متر بر ثانيه) \\
\hline . /KFV & W/IVe & 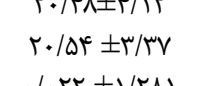 & تجربيى & قدرت ينجه دست (كيلوكَرم) \\
\hline - /AFF & . /195 & $\begin{array}{l}\cdot / \cdot T \pm I / T \Lambda 1 \\
-\cdot / T V \Delta \pm r / \% Y\end{array}$ & كتبربى & نمره Z جاقى استئوسار كوينيك \\
\hline - /EAT & $-\cdot / V \Delta V$ & $\begin{array}{l}\Delta V N / F T \pm 1 \cdot \cdot / \mathscr{Q} q \\
\Delta Q T / q \cdot \pm 1 \cdot 1 / q T\end{array}$ & 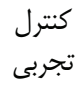 & كيفيت عضلانى \\
\hline שT/AI &.$- / r \mu \Lambda$ & $\begin{array}{l}r / \| F \pm \cdot / \Delta \Lambda \\
r / \Lambda q \pm \cdot / \mu \varphi\end{array}$ & كتبرل & CAF (ييكو گرم بر ميلى ليتر) \\
\hline
\end{tabular}




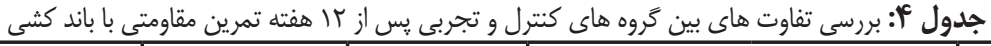

\begin{tabular}{|c|c|c|c|c|c|c|c|}
\hline \multirow{2}{*}{ اندازه اثر } & \multirow{2}{*}{$\mathrm{P}$-value } & \multirow{2}{*}{$\mathrm{F}$} & \multirow{2}{*}{$\Delta \%$} & \multicolumn{2}{|c|}{ زمان } & \multirow{2}{*}{ كروه } & \multirow{2}{*}{ شاخص } \\
\hline & & & & ֶس آزمون & ييش آزمون & & \\
\hline 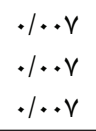 & 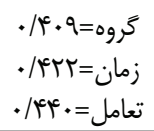 & $\begin{array}{l}.18 \wedge V \\
.190 . \\
.19 \cdot 4\end{array}$ & $\begin{array}{l}r / v r \\
. / \cdot V\end{array}$ & $\begin{array}{l}1) / 99 \pm 1 \cdot / \cdot q \\
1) / A V \pm q / \wedge r\end{array}$ & $\begin{array}{l}V N / V^{\prime} \pm V / \Delta T \\
\Lambda I / \Lambda I \pm N / \cdot r\end{array}$ & كتربى & وزن (كيلوكَرم) \\
\hline $\begin{array}{l}.+\cdot 1 \\
. / 194 \\
. / \cdot r .\end{array}$ & 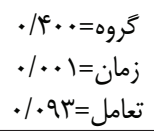 & 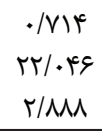 & $\begin{array}{l}q / 1 V \\
r / T q\end{array}$ & 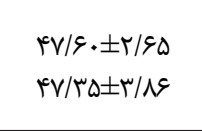 & 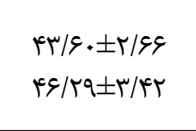 & كتربى & درصد خربى (\%) \\
\hline $\begin{array}{l}. \cdot 11 \\
.+.4 \\
.+.4\end{array}$ & 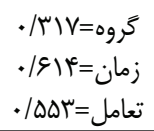 & $\begin{array}{l}. / 1 T \\
. / T \Delta S \\
. / T \Delta P\end{array}$ & $\begin{array}{l}r / 4 Q \\
-\cdot / T \mid\end{array}$ & 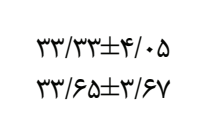 & 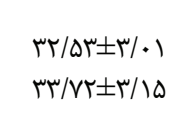 & كتربى & 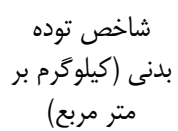 \\
\hline $\begin{array}{l}.1 \cdot r . \\
.+\cdot 1 \\
.+\cdot 1\end{array}$ & 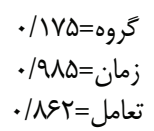 & $\begin{array}{l}1 / \wedge \notin \wedge \\
. / \cdot 1 \\
. / \cdot r\end{array}$ & $\begin{array}{l}-. / 94 \\
. / 19\end{array}$ & $\begin{array}{l}r / \| \pm \cdot / \Delta r \\
r / r q \pm \cdot / r^{4}\end{array}$ & $\begin{array}{l}r / T \pm \cdot / \Delta \cdot \\
r / r \Psi \pm \cdot / r \Lambda\end{array}$ & كنترل & (كرم) BMC \\
\hline $\begin{array}{l}+1+c^{c} \\
+1+1 \\
+1+\varphi^{c}\end{array}$ & 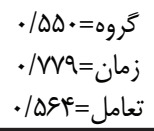 & $\begin{array}{l}. / 4 g . \\
. / \cdot v q \\
. / 4 \pi \Delta\end{array}$ & $\begin{array}{l}-\Delta / V V \\
1 / V T\end{array}$ & $\begin{array}{l}. / Q P V \pm \cdot / T V F \\
. / Q Y \Delta D=/ T V I\end{array}$ & $\begin{array}{l}1 / \cdot \Delta \pm \cdot / \& \Delta \cdot \\
\cdot / q \neg q \pm \cdot / T F \Delta\end{array}$ & كتربى & $\begin{array}{l}\text { سانتى متر مربع) (كَرم بر } \\
\text { BMD }\end{array}$ \\
\hline $\begin{array}{l}.1 \cdot 4 . \\
.+\cdot 1 \\
.1 \cdot 19\end{array}$ & 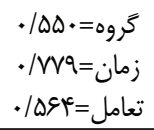 & $\begin{array}{l}\text { I/AET } \\
. /+1 \\
\text { I/DYF }\end{array}$ & $\begin{array}{l}-r / l f \\
r / q r\end{array}$ & $\begin{array}{l}\cdot|c| \varepsilon \pm \cdot / \cdot V \Delta \\
\cdot / \digamma \Delta \mid \pm \cdot / \cdot V \Delta\end{array}$ & 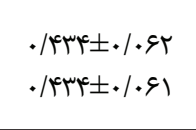 & كتربى & سرعت راه رفتن \\
\hline $\begin{array}{l}.1 . v 9 \\
.1 . .8 \\
.1 .90\end{array}$ & 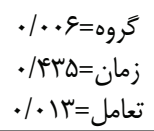 & $\begin{array}{l}\text { V/AMD } \\
. / 8 \mid Q \\
9 / 411\end{array}$ & 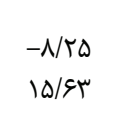 & $\begin{array}{l}\mid N / V q \pm \Delta / \varepsilon . \\
r r / V \Delta \pm \Delta / r \mid\end{array}$ & $\begin{array}{l}r \cdot / \tau \Lambda \pm r / / r \\
r \cdot / \Delta r \pm r / r r\end{array}$ & كتربى & دست (كيلو گرم) \\
\hline $\begin{array}{l}.1 .04 \\
.1 .91 \\
.1 .99\end{array}$ & 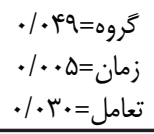 & $\begin{array}{l}r / \Delta A T \\
\mid r / \Delta V q \\
V / . q 1\end{array}$ & 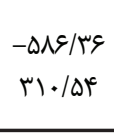 & $\begin{array}{l}-\cdot / l \cdot V \pm 1 / q u \wedge \\
\cdot / \Delta \vee q \pm 1 / q r r\end{array}$ & $\begin{array}{l}\cdot / \cdot r T \pm 1 / r \Lambda 1 \\
-\cdot / r V \Delta \pm I / q \cdot 1\end{array}$ & كنترل & استئوسار كوينيك Zاقى \\
\hline 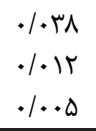 & 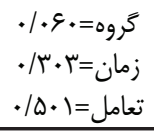 & $\begin{array}{l}\text { W/gr. } \\
1 / \cdot V T \\
+/ 4 \Delta G\end{array}$ & $\begin{array}{l}.1 .90 \\
0 / M\end{array}$ & $\begin{array}{l}r / \mid v \pm \cdot / r q \\
r / \cdot q \pm \cdot / q)\end{array}$ & $\begin{array}{l}r / / f \pm \cdot / \Delta \Lambda \\
r / \Lambda q \pm \cdot / r^{4}\end{array}$ & كتربى & $\begin{array}{c}\text { Cبر ميلى ليتر) CAF } \\
\text { (ييكوم }\end{array}$ \\
\hline $\begin{array}{l}.1 \cdot 49 \\
.1 .94 \\
.1 .44\end{array}$ & 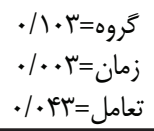 & $\begin{array}{l}\text { r/VIr } \\
\text { q/DQ. } \\
r / r r \Delta\end{array}$ & $\begin{array}{l}r / \mathscr{L} \\
r / q \varepsilon\end{array}$ & $\begin{array}{l}q \cdot r / r \Delta \pm I r \cdot / q \tau \\
q q 1 / v \cdot \pm 1 r \cdot / r \omega\end{array}$ & $\begin{array}{l}\Delta V N / F r \pm 1+. / F G \\
\Delta F H / q \cdot \pm 1 \cdot 1 / q r\end{array}$ & كتربى & كيفيت عضلانى \\
\hline
\end{tabular}

با نتايج يزوهش حاضر هافمن و همكاران نشان دادند كه كيفيت عضلانى پِ از سّ و و ماه تمرين مقاومتى با باند الاستيك حتى در زنان بسيار سالخورده بهبود معنى دارى مى يابد. سونگ و همكاران

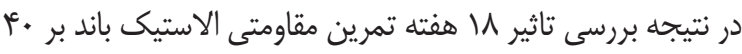

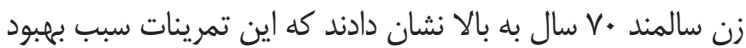
كيفيت عضلانى در اين زنان شده است (ب).). همجنين در تحقيقى كه رونى سيلوريا و همكاران بر زنان سالمند كزارش كردند كه دوره كوتاه شش هفته تمرينات قدرتى با دستخاه

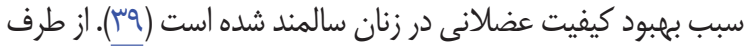
ديخر بارونى و همكاران در نتيجه بررسى تاثير rا هفته تمرينات

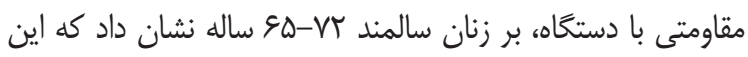

هدف از يزوهش حاضر بررسى تاثير r إ هفته تمرين مقاومتى با باند كشى بر كيفيت عضلانى و غلظت سرمى CAF در زنان سالمند داراى خاقى استئوسار كوينيك بود. نتايج يزوهش حاضر نشان داد كه r| هفته تمرين مقاومتى

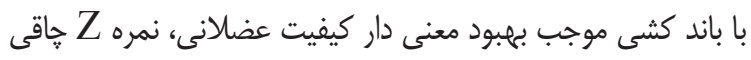

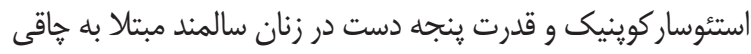
استئوساركوينيك مى شود، با اين حال تفاوت معنى دارى در وزن بدن، درصد جربى، BMI، BMC، BMD، سرعت راه رفتن و CAF در زمينه تاثير تمرينات مقاومتى بر كيفيت عضلانى همسو 
خون افراد سالمند مشاهده كردند (19). از طرف ديكر بونداك و

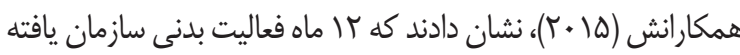
(شامل تركيبى از انواع تمرينات ورزشى) تاثير معنى دارى بر سطوح

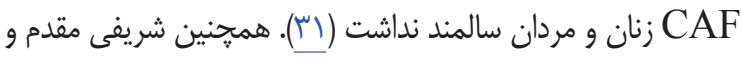

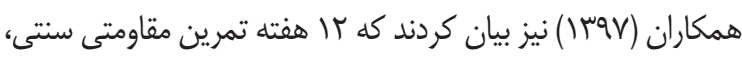
باو بدون محدوديت جريان خون موجب تغيير معنى دارى در سطوح

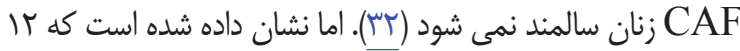

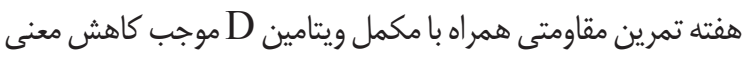

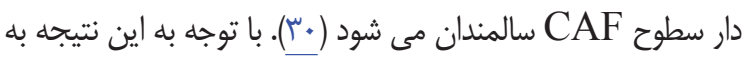
نظر مى رسد نقش تغذيه و بويزه مصرف ويتامين D در كاهش سطوح CAF و حفظ و نكمهدارى ييوندكاه عصبى عضلانى غير قابل انكار است. همجنين فعاليت بيش از حد نروترويسين به عنوان عامل

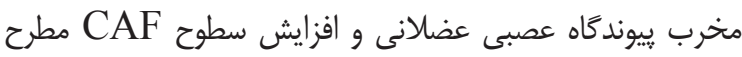

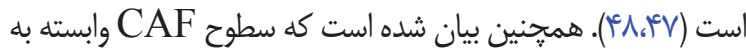
جنسيت است و به دليل توده عضلانى بيشتر در مردان اين تغييرات

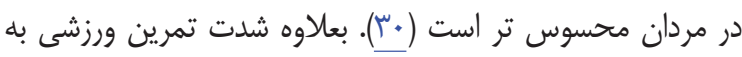

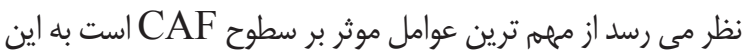
صورت كه تمرينات با شدت بالاو تمرينات توانى نسبت به تمرينات

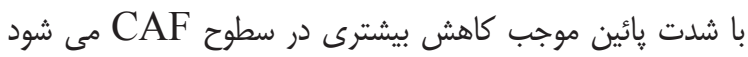

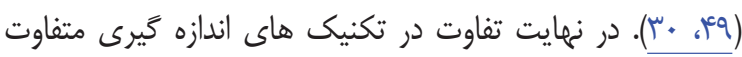
(الايزا در مقابل روش دقيق تر وسترن بلات) مى تواند يكى ديخر از

دلايل اصلى تفاوت در نتايج يزوهش ها باشد (وَ). در مطالعه حاضر همسو با عدم تغيير در CAF تغيير معنى دارى در سرعت راه رفتن مشاهده نشد در حالى كه افزايش معنى داصنى دارى در قدرت ينجه دست مشاهده شد. بونداك و همكاران (ها • (Y)، و دراى و همكاران (T/ +(T)، بيان كردند كه ارتباط معنى دارى بين سرعت راه رفتن با سطوح CAF وجود دارد در حالى كه اين ارتباط

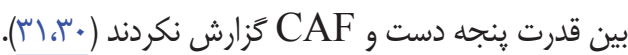
با وجود كنترل دقيق بسيارى از شرايط مورد اهميت در يزوهش حاضر از جمله انجام آزمايش دَزا و انتخاب حجم نمونه

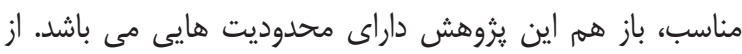

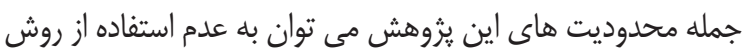
وسترن بلات اشاره كرد. همجنين عدم كنترل دقيق رزيم غذايى و انجام مداخلات تتذيه اى از جمله محدوديت هاى ديخًر اين يزوهش مى باشد.

\section{تنتيجه كيرى نهائى}

در مجموع با توجه به نتايج يزوهش به نظر مى رسد تمرين
تمرينات تاثيرى بر كيفيت عضلانى زنان سالمند نداشته است (•ما). علت نا همخوانى اين يزوهش با يزوهش حاضر مى تواند تفاوت در

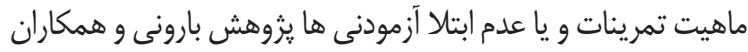

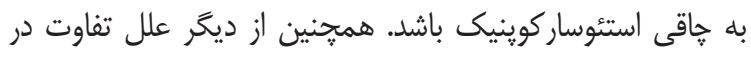

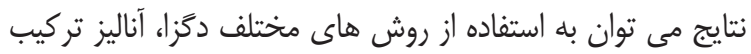
بدن و سونوگرافى براى تعيين كيفيت عضلانى نام برد (بأ، أا). از طرف ديخر به نظر مى رسد بهبود كيفيت عضلانى ناشى از تمرينات مقاومتى ناشى از مسدود شدن جريان هاى تجزيه بروتئين هاى

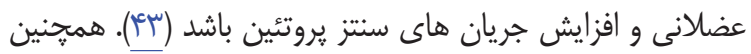
با وجود اينكه در يزوهش حاضر مورد اندازه كيرى قرار نكَرفت، اما افزايش سطوح فوليستاتين و هورمون رشد شبه انسولين و كاهش

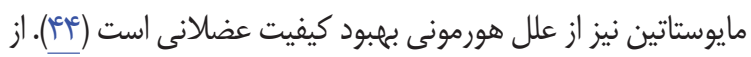
طرف ديخر افزايش معنى دار در قدرت كرفتن دست و افزايش غير

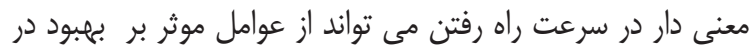
كيفيت عضلانى باشد (ه) (I).

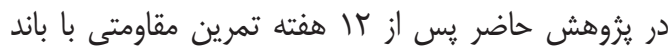
الاستيك نمره Z استئوساركوينيك زنان مبتلا به خاقى استئو سار كوينيك به طور معنى دارى افزايش يافت. از آنجا كه اين نمره يك نمره هند عاملى (كيفيت عضلانى، قدرت عضلانى، קُكالى و تراكم مواد معدنى استخوان، درصد جربى) مى باشد مطالعات بسيار اندكى به بررسى جامع اين شاخص يرداختند. تقريبا تنها مطالعه اى

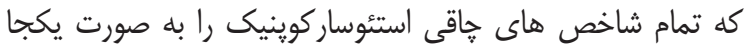

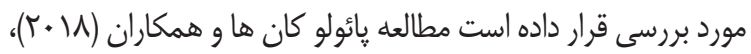

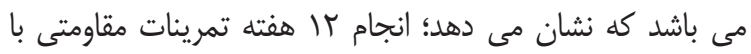
دستخاه در زنان سالمند داراى קاقى استئوساركوينيك در محدوده

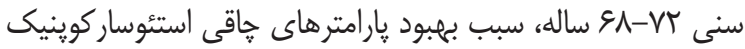

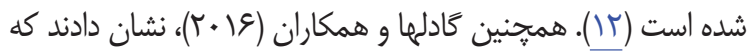
يك دوره ז هفته اى تمرين مقاومتى در زنان سالمند خاق منجر به

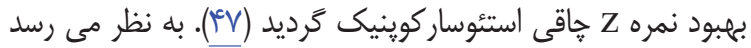
بهبود معنى دار در نمره Z هاقى استئوسار كوينيك در يزوهش حاضر ناشى از بهبود معنى دار كيفيت عضلانى، قدرت عضلانى (قدرت

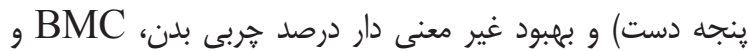
BMD اما در يزوهش حاضر سطوح CAF پِس از זا هفته تمرين

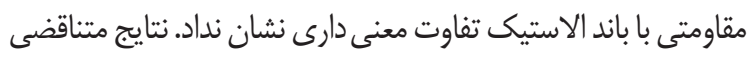
و محدودى در مورد تاثير انواع تمرينات مقاومتى بر سطوح CAF وجود دارد. به طورى كه از طرفى فراكالا و همكاران (أ +r)، در

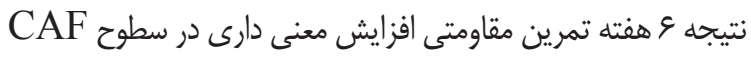




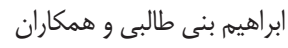

$$
\begin{aligned}
& \text { توجه به عدم تغيير معنى دار CAF و عدم ارتباط با شاخص كيفيت }
\end{aligned}
$$

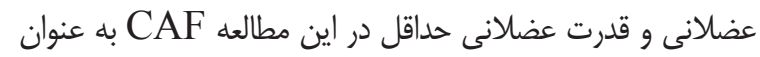

$$
\begin{aligned}
& \text { نشانكَر قدر تمند كيفيت عضلانى و عملكرد جسمانى تاييد نمى شود. } \\
& \text { با اين وجود با توجه به عدم انجام تحقيقات جامع و كامل در اين زمينه }
\end{aligned}
$$

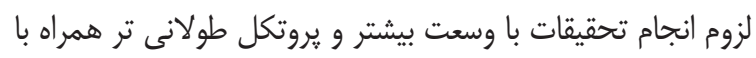

$$
\begin{aligned}
& \text { كنترل دقيق شاخص هاى غذايى به شدت احساس مى شود. }
\end{aligned}
$$

\section{References}

1. Nikolich-Zugich J. The aging immune system: challenges for the 21 st century. In Seminars in immunology. 2012; 24: 301. NIH Public Access.

2. Tramontano A, Veronese N, Sergi G, Manzato E, Rodriguez-Hurtado D, Maggi S, et al. Prevalence of sarcopenia and associated factors in the healthy older adults of the Peruvian Andes. Archives of gerontology and geriatrics. 2017; 68: 49-54.

3. Ormsbee MJ, Prado CM, Ilich JZ, Purcell S, Siervo M, Folsom A, et al. Osteosarcopenic obesity: the role of bone, muscle, and fat on health. Journal of cachexia, sarcopenia and muscle. 2014; 5 (3):183-92.

4. Shirazi-Fard Y, Kupke JS, Bloomfield SA, Hogan HA. Discordant recovery of bone mass and mechanical properties during prolonged recovery from disuse. Bone. 2013; 52 (1):433-43.

5. Kelly TL, Wilson KE, Heymsfield SB. Dual energy X-Ray absorptiometry body composition reference values from NHANES. PloS one. 2009;4 (9):e7038.

6. Cruz-Jentoft AJ, Baeyens JP, Bauer JM, Boirie Y, Cederholm T, Landi F, et al. Sarcopenia: European consensus on definition and diagnosis Report of the European Working Group on Sarcopenia in Older People. Age and ageing. 2010; 39 (4): 412-23.

7. Ilich J, Inglis J, Kelly O, McGee D. Osteosarcopenic obesity is associated with reduced handgrip strength, walking abilities, and balance in postmenopausal women. Osteoporosis International. 2015; 26 (11): 2587-95.

8. Hita-Contreras F, Martínez-Amat A, CruzDíaz D, Pérez-López FR. Osteosarcopenic obesity and fall prevention strategies.
مقاومتى با باند الاستيك موجب بهبود قدرت عضلانى، كيفيت

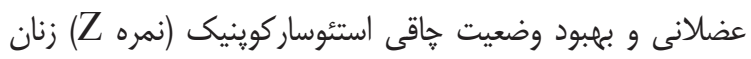
سالمند مبتلا به حاقى استئوسار كوينيك مى شود. بنابراين با توجه به إنها

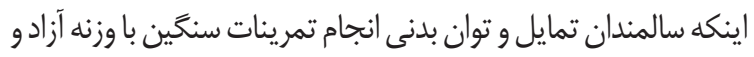

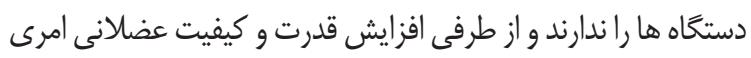
ضرورى براى اين افراد است براى دستيابى به اهداف تمرينى استفاده

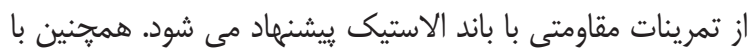

Maturitas. 2015; 80 (2): 126 - 32.

9. Topinková E. Aging, disability and frailty. Annals of Nutrition and Metabolism. 2008; 52: 6-11.

10. Booth FW, Gordon SE, Carlson CJ, Hamilton MT. Waging war on modern chronic diseases: primary prevention through exercise biology. Journal of applied physiology. 2000; 88 (2):774 - 87.

11. Ilich JZ, Brownbill RA. Habitual and lowimpact activities are associated with better bone outcomes and lower body fat in older women. Calcified tissue international. 2008; 83 (4): 260-71.

12. Cunha PM, Ribeiro AS, Tomeleri CM, Schoenfeld BJ, Silva AM, Souza MF, et al. The effects of resistance training volume on osteosarcopenic obesity in older women. Journal of Sports Sciences. 2018; 36 (14):1564-71.

13. Jafari Nasabian P, Inglis JE, Kelly OJ, Ilich JZ. Osteosarcopenic obesity in women: impact, prevalence, and management challenges. International journal of women's health. 2017;9:33.

14. Fiatarone MA, O'Neill EF, Ryan ND, Clements KM, Solares GR, Nelson ME, et al. Exercise training and nutritional supplementation for physical frailty in very elderly people. New England Journal of Medicine. 1994; 330 (25): 1769-75.

15. Häkkinen K, Kraemer WJ, Pakarinen A, Tripleltt-Mcbride T, Mcbride JM, Häkkinen A, et al. Effects of heavy resistance/power training on maximal strength, muscle morphology, and hormonal response patterns in 60-75-year-old men and women. Canadian Journal of Applied Physiology. 2002; 27 (3): 213-31.

16. Izquierdo M, Häkkinen K, Ibanez J, Garrues M, Anton A, Zuniga A, et al. Effects of 
strength training on muscle power and serum hormones in middle-aged and older men. Journal of Applied Physiology. 2001; 90 (4): 1497-507.

17. Aagaard P, Suetta C, Caserotti P, Magnusson SP, Kjær M. Role of the nervous system in sarcopenia and muscle atrophy with aging: strength training as a countermeasure. Scandinavian journal of medicine \& science in sports. 2010; 20 (1): 49-64.

18. Hills AP, Shultz SP, Soares MJ, Byrne NM, Hunter GR, King NA, et al. Resistance training for obese, type 2 diabetic adults: a review of the evidence. Obesity reviews. 2010; 11(10):740-9.

19. Yasuda T, Fukumura K, Fukuda T, Iida $\mathrm{H}$, Imuta H, Sato Y, et al. Effects of lowintensity, elastic band resistance exercise combined with blood flow restriction on muscle activation. Scandinavian journal of medicine \& science in sports. 2014; 24 (1):55-61.

20. Colado JC, Triplett NT. Effects of a shortterm resistance program using elastic bands versus weight machines for sedentary middle-aged women. The Journal of Strength \& Conditioning Research. 2008; 22 (5): 1441-8.

21. Hofmann M, Schober-Halper B, Oesen S, Franzke B, Tschan H, Bachl N, et al. Effects of elastic band resistance training and nutritional supplementation on muscle quality and circulating muscle growth and degradation factors of institutionalized elderly women: the Vienna Active Ageing Study (VAAS). European journal of applied physiology. 2016; 116 (5): 885 - 97.

22. Ferrari R, Fuchs SC, Kruel LF, Cadore EL, Alberton CL, Pinto RS, et al. Effects of different concurrent resistance and aerobic training frequencies on muscle power and muscle quality in trained elderly men: a randomized clinical trial. Aging and disease. 2016; 7 (6): 697.

23. De La Haba G, Kamali HM, Tiede DM. Myogenesis of avian striated muscle in vitro: role of collagen in myofiber formation. Proceedings of the National Academy of Sciences. 1975; 72 (7): 2729 - 32.

24. Prockop DJ, Kivirikko KI, Tuderman L, Guzman NA. The biosynthesis of collagen and its disorders. New England Journal of Medicine. 1979; 301 (2): 77-85.

25. Bolliger MF, Zurlinden A, Lüscher D, Bütikofer L, Shakhova O, Francolini M, et al. Specific proteolytic cleavage of agrin regulates maturation of the neuromuscular junction. J Cell Sci. 2010; 123 (22): 3944 55.

26. Bütikofer L, Zurlinden A, Bolliger MF, Kunz B, Sonderegger P. Destabilization of the neuromuscular junction by proteolytic cleavage of agrin results in precocious sarcopenia. The FASEB Journal. 2011; 25 (12): 4378-93.

27. Nishimune H, Stanford JA, Mori Y. Role of exercise in maintaining the integrity of the neuromuscular junction. Muscle \& nerve. 2014; 49 (3): 315-24.

28. Hettwer S, Dahinden P, Kucsera S, Farina C, Ahmed S, Fariello R, et al. Elevated levels of a C-terminal agrin fragment identifies a new subset of sarcopenia patients. Experimental gerontology. 2013; 48 (1): 69-75.

29. Fragala MS, Jajtner AR, Beyer KS, Townsend JR, Emerson NS, Scanlon TC, et al. Biomarkers of muscle quality: Nterminal propeptide of type III procollagen and Cterminal agrin fragment responses to resistance exercise training in older adults. Journal of cachexia, sarcopenia and muscle. 2014; 5 (2): 139-48.

30. Drey M, Sieber CC, Bauer JM, Uter W, Dahinden P, Fariello RG, et al. C-terminal Agrin Fragment as a potential marker for sarcopenia caused by degeneration of the neuromuscular junction. Experimental gerontology. 2013; 48 (1): 76-80.

31. Bondoc I, Cochrane SK, Church TS, Dahinden P, Hettwer S, Hsu FC, et al. Effects of a one-year physical activity program on serum C-terminal Agrin Fragment (CAF) concentrations among mobility-limited older adults. The journal of nutrition, health \& aging. 2015; 19 (9): 922-7.

32. Sharifi Moghadam A, Askari R, Hamedinia MR, Haghighi AH. The Effect of Resistance Training with and without Blood Flow Restriction on Serum Concentration of CAF, P3NP and Muscular Function in Elderly Women. Journal of sport biosciences. 2018;10 (3): 359-75. 
33. Boutron I, Altman DG, Moher D, Schulz KF, Ravaud P. CONSORT statement for randomized trials of nonpharmacologic treatments: a 2017 update and a CONSORT extension for nonpharmacologic trial abstracts. Annals of internal medicine. 2017;167 (1): 40-7.

34. De Liao C, Tsauo JY, Lin LF, Huang SW, $\mathrm{Ku} \mathrm{JW}$, Chou LC, et al. Effects of elastic resistance exercise on body composition and physical capacity in older women with sarcopenic obesity. Medicine (United States). 2017; 96 (23).

35. Balachandran A, Krawczyk SN, Potiaumpai M, Signorile JF. High-speed circuit training vs hypertrophy training to improve physical function in sarcopenic obese adults: a randomized controlled trial. Experimental gerontology. 2014; 60: 64-71.

36. Efird J. Blocked randomization with randomly selected block sizes. International journal of environmental research and public health. 2010; 8 (1):15-20.

37. Lagally KM, Robertson RJ. Construct validity of the OMNI resistance exercise scale. Journal of Strength and Conditioning Research. 2006; 20 (2): 252.

38. Oh SL, Kim HJ, Woo S, Cho BL, Song M, Park YH, et al. Effects of an integrated health education and elastic band resistance training program on physical function and muscle strength in community-dwelling elderly women: Healthy Aging and Happy Aging II study. Geriatrics \& gerontology international. 2017;17 (5):825-33.

39. Pinto RS, Correa CS, Radaelli R, Cadore EL, Brown LE, Bottaro M. Short-term strength training improves muscle quality and functional capacity of elderly women. Age. 2014; 36 (1): 365-72.

40. Correa CS, Baroni BM, Radaelli R, Lanferdini FJ, Cunha GD, ReischakOliveira Á, et al. Effects of strength training and detraining on knee extensor strength, muscle volume and muscle quality in elderly women. Age. 2013; 35 (5): 1899-904.

41. Kennis E, Verschueren S, Van Roie E, Thomis M, Lefevre J, Delecluse C. Longitudinal impact of aging on muscle quality in middleaged men. Age. 2014; 36 (4): 9689.

42. Straight CR, Brady AO, Evans EM.
Muscle quality and relative adiposity are the strongest predictors of lower-extremity physical function in older women. Maturitas. 2015; 80 (1): 95-9.

43. Ziaaldini MM, Koltai E, Csende Z, Goto S, Boldogh I, Taylor AW, et al. Exercise training increases anabolic and attenuates catabolic and apoptotic processes in aged skeletal muscle of male rats. Experimental gerontology. 2015; 67:9-14.

44. Kerschan-Schindl K, Thalmann MM, Weiss E, Tsironi M, Föger-Samwald U, Meinhart J, et al. Changes in serum levels of myokines and Wnt-antagonists after an ultramarathon race. PloS one. 2015; 10 (7): e0132478.

45. Oesen S, Halper B, Hofmann M, Jandrasits W, Franzke B, Strasser EM, et al. Effects of elastic band resistance training and nutritional supplementation on physical performance of institutionalised elderly-A randomized controlled trial. Experimental gerontology. 2015; 72: 99-108.

46. Gadelha AB, Paiva FM, Gauche R, de Oliveira RJ, Lima RM. Effects of resistance training on sarcopenic obesity index in older women: a randomized controlled trial. Archives of gerontology and geriatrics. 2016;65:168-73.

47. Fragala MS, Kenny AM, Kuchel GA. Muscle quality in aging: a multi-dimensional approach to muscle functioning with applications for treatment. Sports Medicine. 2015; 45 (5): 641-58.

48. Landi F, Calvani R, Lorenzi M, Martone AM, Tosato M, Drey M, et al. Serum levels of C-terminal agrin fragment (CAF) are associated with sarcopenia in older multimorbid community-dwellers: results from the ilSIRENTE study. Experimental gerontology. 2016 15; 79: $31-6$.

49. Deschenes MR, Maresh CM, Crivello JF, Armstrong LE, Kraemer WJ, Covault J. The effects of exercise training of different intensities on neuromuscular junction morphology. Journal of neurocytology. 1993; 22 (8): 603-15. 